\title{
The Role of Effective Communication in School Achievement
}

\author{
${ }^{1}$ Biji Nair, ${ }^{2}$ Abhaya R. Joglekar \\ ${ }^{1}$ Research Scholar \& Asstt. Prof. Vivekanand College, Kota. \\ ${ }^{2}$ Prof. of Home Science Govt.Navin kanya college, Raipur
}

\begin{abstract}
Success of any knowledge and education depends upon the communication. On the basis of above study, approximately $81.33 \%$ girls were affected with the personality of teacher. The study recommends that there should be combination of traditional and new exploratory method as a teaching aid for better achievement in life.
\end{abstract}

\section{Introduction-}

Success of any knowledge and education depends upon the communication. The oral communication has been derived from the Latin word "communes" means common and hence communication is sharing common experiences with people.

Teaching is a two way process where there is one receiver (student) and giver (teacher). The teacher shares his knowledge and experiences with the students. A teacher plays an important role in overall development of a student. Personality of any student depend upon the teacher how he communicate his knowledge. The teacher is responsible not only for the pertaining knowledge but also for social, psychological, moral development of a student. Several studies carried out in this field support the fact.

The main objective of the effective communication is to motivate, inform, suggest, warn, order to change behavior, establish better relation with others to make learning meaningful and understood.

A communicator is effective when he is competent, sincere and dynamic. The message that the communicator wants to communicate is communicated when it is acknowledged, understood, reacted, responded and shaped into learning behavior. In classroom communication teacher must know several thing about communication. Developing communication skills among children should be the basic concern of the school and hence, teachers must provide ways and means of developing and improving their skills.

Keeping this view in mind the present study was designed to find out the effective communication method in school teaching.

Selection of school:-

II. Material and Method:-

Govt. Sant Kanwar Ram Higher Secondary School, Katora Talab, Raipur was selected for the study.

\section{Selection of sample:-}

60 girls between the age groups of 16-17 yrs. Of age were randomly selected for the present study.

Assessment of effective communication method:-

The effective communication method was examined by using self made questionnaire. 40 questions regarding subject matter, education type, personality of teacher, teacher student relationship, methods were used for the study.

Statistical analysis:-The data were statistical analyzed by using mean and standard deviation, methods.

III. Results and Discussion:-

Table no. 1- shows sex and No. of student

\begin{tabular}{|l|l|}
\hline $\begin{array}{l}\text { Sex } \\
\text { Girl's }\end{array}$ & No. of student \\
\hline $16-17$ yrs. & 60 \\
\hline
\end{tabular}


The Role Of Effective Communication In School Achievement

Table no. 2- Distribution of different particulars contained.

\begin{tabular}{|l|l|l|}
\hline Particulars contained & $\begin{array}{l}\text { Mean and std. deviation } \\
\text { N=60 }\end{array}$ & $\%$ \\
\hline Subject matter & $6.83 \pm 1.46$ & 68.33 \\
\hline Education type & $7.33 \pm 1.49$ & $\mathbf{7 3 . 3 3}$ \\
\hline Personality of teacher & $\mathbf{8 . 7 3} \underline{\mathbf{0} .84}$ & $\mathbf{8 1 . 3 3}$ \\
\hline Teacher-student relation & $\mathbf{7 . 8 3}+1.57$ & $\mathbf{7 8 . 3 3}$ \\
\hline
\end{tabular}

Table no. 2 depicts the effective communication measures of the students. The result reveals that $81.33 \%$ students were affected by the personality of the teacher $(\mathbf{8 . 7 3} \pm \mathbf{0 . 8 4}), 73.33 \%$ students were more affect by the type of education. Whereas $68.33 \%$ responded were represented the subject matter should be clear. 78.33 $\%$ students accepted the student teacher relation was responsible for their performance.

The overall result reveals that teacher student relationship should be more transparent. As several researches proved that there is a positive relation between teacher student relationship and scholastic performance. Similarly the personalities of teacher attract the student and enhance their ability.

\section{Conclusions-}

Teacher must know several things about communication. Classrooms are setup for the purpose of communicating and not for imposing teacher's ideas on young and growing minds. Developing communication skills among children should be the basic concern of the school and hence, teachers must provide ways and means of developing and improving their skills.

Communication in classroom can occur only when teacher and the student share common meaning and experiences. Students with widely different backgrounds, different abilities and interests attend school. Further, the teacher has to manage with the vast explosion in knowledge and the fact that student have too little time to explore the vast subject matter included in the curriculum. To meet these challenges, the teacher has to make use of new and improved communication devices in classroom like films, projector, internet, etc.

\section{Acknowledgement-}

I am thankful to smt. Raji Nair, lecture of Govt. Sant Kanwar Ram Higher Secondary School, Katora Talab, Raipur for their valuable corporation. I am also thankful to students of Govt.Sant Kanwar ram higher secondary school's $11^{\text {th }}$ standards students without whom I could not complete my work. I am also thankful to Proffesor Dr. Abhaya R. Joglekar for her consistent direction.

\section{Reference:-}

[1]. Rao. Usha educational technology, Himalaya publishing house, Mumbai Bhatnager, R.P. (2007), Educational technology and management, international publishing house.

[2]. Rawat, S.C., Educational technology and managementDr. J.S.Wadia, edition 2007 Prasad Kiran, communication for development; reinventing theory and action. 